\title{
Trwałość elementów systemu natryskowego i właściwości wytworzonych warstw w funkcji jakości drutów proszkowych
}

\section{Service life of thermal spraying system elements and create surfaces properties as a core wires quality function}

\section{Streszczenie}

Badaniom poddano dwa druty proszkowe o średnicy 1,6 mm pochodzące od różnych producentów, przeznaczone do natryskiwania cieplnego warstw o podwyższonej odporności na zużycie erozyjne. Druty zbadano pod względem jakości drobin sypkiego rdzenia, jakości powierzchni metalowej otoczki oraz jej geometrii. Badane druty wykorzystano do wytworzenia warstw wierzchnich metodą łukową. Otrzymane warstwy analizowano z uwagi na mikrostrukturę, skład chemiczny, porowatość twardość oraz osadzenie warstw w podłożu stalowym. Określono trwałość wybranych elementów systemu natryskowego dla każdego z drutów.

\section{Abstract}

Two cored wires which diameter is a $1.6 \mathrm{~mm}$ has been investigated. Wires came from the other manufacturers and appropriated to thermal spraying of erosion wear surface layer. The wires have been examined for the sake of chemical composition of the metallic tape and the core, wire surface quality and geometry of metal halo. Wires have been used to surface layers creation by arc spraying. The fabricated layers analyzed in respect of microstructure, chemical composition, porosity, hardness and surface deposition on substrate steel material. Service life of spraying system selected elements for each wire has been determined.

\section{Wstęp}

Zastosowanie metalicznych materiałów powłokowych do wytwarzania warstw zabezpieczających przed destrukcyjnym działaniem środowiska w warunkach eksploatacyjnych jest działaniem ważnych $w$ przemyśle energetycznym. W tym aspekcie wykorzystuje się metody napawania, gdzie dochodzi do wymieszania się składników w jeziorku spawalniczym oraz metody natryskiwania cieplnego bez mieszania się materiału powłokowego z podłożem lub gdzie stopień wymieszania jest bardzo niewielki. Ponadto metody napawania wykazują zdecydowanie większą ilość wprowadzonego ciepła.

Dr inż. Artur Wypych - Politechnika Poznańska.
Występujące gradienty temperatury zarówno podczas nagrzewania, jak i stygnięcia dają efekt w postaci naprężeń cieplnych i przemian mikrostrukturalnych w obszarze występującej przy napawaniu strefy wpływu ciepła w materiale rodzimym. Zmiany kształtu i wymiarów oraz stosowanie zabiegów dodatkowych przed i po napawaniu generują pewne ograniczenia i utrudnienia technologiczne, a także dodatkowe koszty w przypadku napawania detali cienkościennych. Rozwiązaniem tego problemu może być wytworzenie warstwy wierzchniej za pomocą natryskiwania łukowego, gdzie temperatura materiału rodzimego nie przekracza wartości występowania przemian w mikrostrukturze i naprężenia cieplne zostają zredukowane $[1 \div 3]$.

Celem badań było porównanie stosowanych na dużą skalę w przemyśle materiałów powłokowych do natryskiwania w postaci drutów proszkowych o takim 
samym przeznaczeniu, technologii wytwarzania i składzie chemicznym, oferowanych przez różnych producentów, pod względem ich jakości, właściwości warstw i zużywania się elementów systemu natryskowego.

Podjęto próbę wytworzenia warstw o podwyższonej twardości i odporności na zużycie erozyjne za pomoca natryskiwania łukowego. Zastosowano druty proszkowe dostępne w katalogach producentów o składzie chemicznym podanym w tablicy I. Druty wytworzono z taśmy metalowej prasowanej przez ciągnienie, w której wnętrzu umieszczono sypki rdzeń. Takie materiały powłokowe do natryskiwania nie są dostępne z otoczką w postaci rurki bezszwowej, co dotychczas uniemożli-

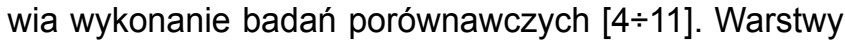
natryskiwano za pomocą pistoletu LD/U2 z układem zamkniętym dyszy, dającym efekt zmniejszania wymiaru cząstek natryskiwanych, produkcji Sulzer Metco, współpracującym ze źródłem Flexi Arc 300 tej samej firmy [12]. Zastosowano następujące podstawowe parametry procesu: odległość natryskiwania $150 \mathrm{~mm}$, natężenie prądu natryskiwania $190 \mathrm{~A}$, napięcie łuku 30 V, grubość powłoki natryskiwanej $500 \mu \mathrm{m}$.

\section{Badanie jakości drutów proszkowych}

Druty oznaczone symbolami A i B wytworzone $\mathrm{z}$ taśmy poddano badaniom pod kątem morfologii sypkiego rdzenia. W przypadku drutu A stwierdzono występowanie dużych drobin o rozmiarach zbliżonych, nieregularnym kształcie, na których powierzchni widoczne sa typowe przełomy o kruchym charakterze (rys. 1). Rdzeń drutu B tworzą ziarna proszku o mocno zróżnicowanych wymiarach, nieregularnym kształcie i powierzchni podobnej do rdzenia drutu A (rys. 2). Skład chemiczny rdzenia przedstawiono w tablicy II.

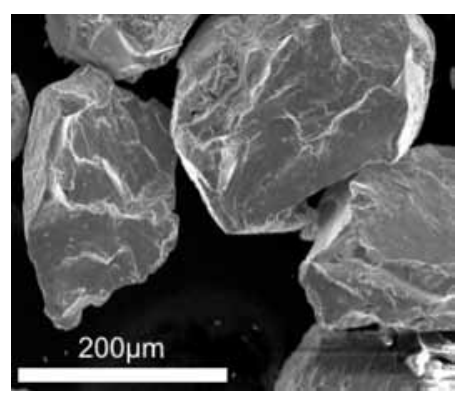

Rys. 1. Obraz ziaren proszku stanowiących sypki rdzeń drutu A, duże ziarna o zbliżonych rozmiarach

Fig. 1. Core particles of wire A, large homothetic sizes particles

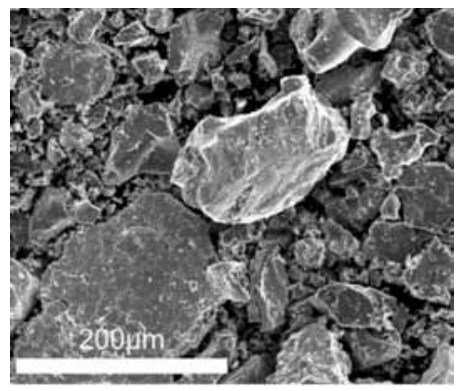

Rys. 2. Obraz ziaren proszku stanowiących sypki rdzeń drutu B, ziarna o znacznie zróżnicowanych rozmiarach Fig. 2. Core particles of wire $\mathrm{B}$, diversified sizes particles
Tablica I. Skład chemiczny drutów A i B według karty charakterystyki producenta

Table I. Chemical composition of A and B wires according to material issue list by manufacturer

\begin{tabular}{|c|c|c|c|c|c|c|}
\hline Pierwiastek, \% wag. & $\mathrm{C}$ & $\mathrm{Si}$ & $\mathrm{Mn}$ & $\mathrm{Cr}$ & $\mathrm{Fe}$ & $\mathrm{B}$ \\
\hline A & 0,09 & 1,3 & 1,2 & 27,3 & baza & 3,55 \\
\hline B & 0,09 & 1,1 & 1,2 & 28,2 & baza & 3,85 \\
\hline
\end{tabular}

Tablica II. Skład chemiczny rdzenia drutów A i B

Table II. Chemical composition of core $A$ and $B$ wires

\begin{tabular}{|c|c|c|c|c|c|}
\hline Pierwiastek, \% wag. & $\mathrm{Si}$ & $\mathrm{Mn}$ & $\mathrm{Cr}$ & $\mathrm{Fe}$ & $\mathrm{B}$ \\
\hline $\mathrm{A}$ & 0,9 & 1,8 & 75,9 & 14,8 & 6,4 \\
\hline B & 5,6 & 3,2 & 79,3 & 4,9 & 6,2 \\
\hline
\end{tabular}

W zakres badania jakości drutów włączono powierzchnię metalowej otoczki utworzonej z taśmy [13]. Wykonano badanie topografii powierzchni drutów (rys. 3 i 4). Zaobserwowano znaczne różnice w jakości powierzchni z uwagi na jej gładkość. Powstałe obrazy przedstawiają znacznie lepszą jakość powierzchni drutu oznaczonego symbolem B niż jakość powierzchni drutu A. Ocenę wizualną zweryfikowano pomiarem chropowatości powierzchni drutów w przypadkowo wybranych miejscach. Dla drutu A stwierdzono wartość

Tablica III. Wyniki pomiaru chropowatości powierzchni drutów Table III. Result the roughness of surface wires measurement

\begin{tabular}{|c|c|c|}
\hline Parametr & $\mathrm{Ra}, \mu \mathrm{m}$ & $\mathrm{Rz}, \mu \mathrm{m}$ \\
\hline A & 1,79 & 60,71 \\
\hline B & 0,90 & 17,18 \\
\hline
\end{tabular}

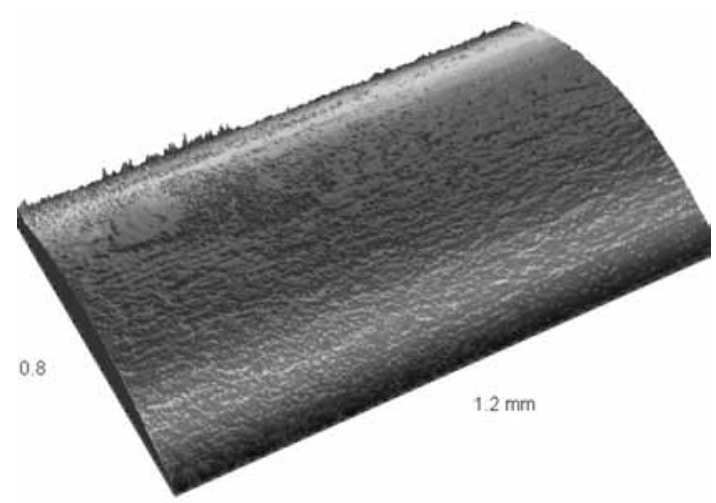

Rys. 3. Topografia powierzchni drutu A z zachowaniem jego kształtu Fig. 3. Surface topography of wire $A$ with shape conservation

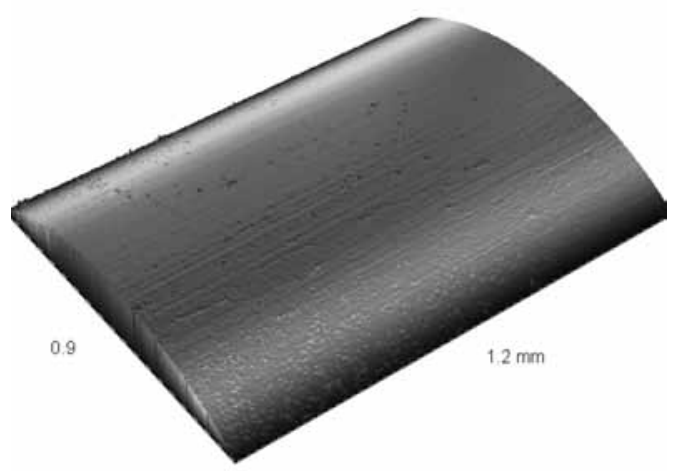

Rys. 4. Topografia powierzchni drutu B z zachowaniem jego kształtu Fig. 4. Surface topography of wire $B$ with shape conservation 


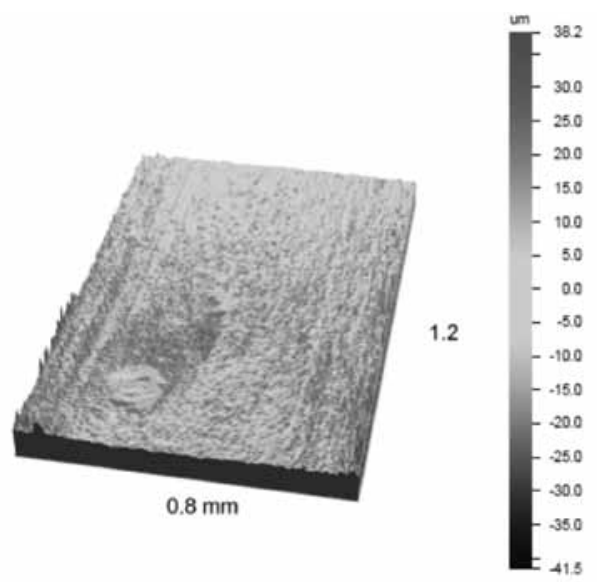

Rys. 5. Powierzchnia drutu A badana podczas pomiaru chropowatości, wartości parametrów Ra i Rz podano w tablicy III

Fig. 5. Wire A surface form during the roughness measurement, value of $\mathrm{Ra}$ and $\mathrm{Rz}$ parameters gave in table III

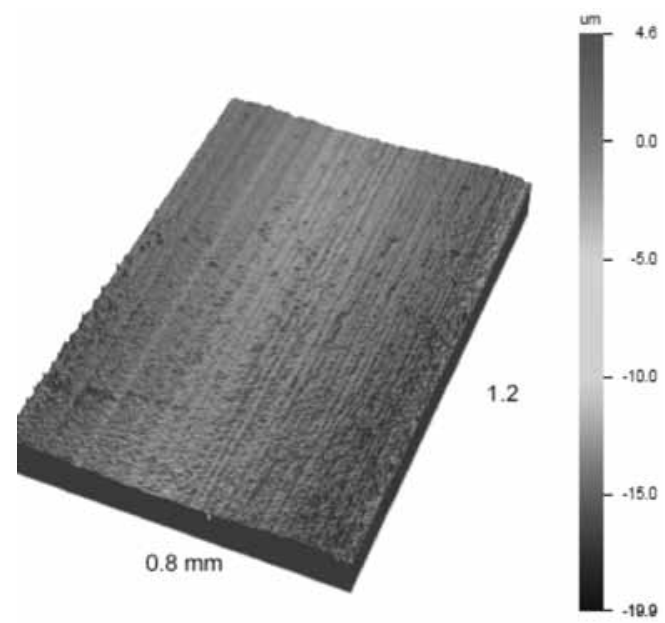

Rys. 6. Powierzchnia drutu $B$ badana podczas pomiaru chropowatości, wartość parametrów Ra i Rz podano w tablicy III

Fig. 6. Wire $B$ surface form during the roughness measurement, value of $\mathrm{Ra}$ and $\mathrm{Rz}$ parameters gave in table III

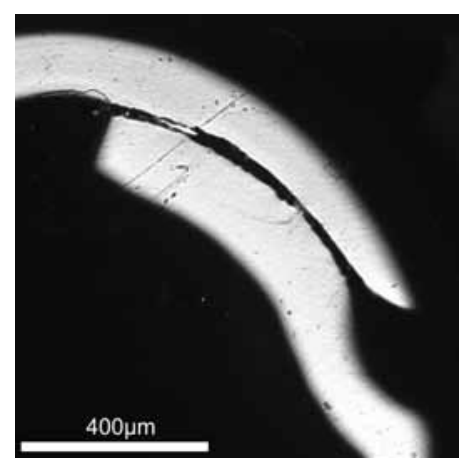

Rys. 7. Przekrój poprzeczny i wielkość zakładki powstałej podczas formowania drutu - dla A wynosi ok. $600 \mu \mathrm{m}$

Fig. 7. Cross-section and size of overlap create during of wire forming process - for $A$ wire it amount about $600 \mu \mathrm{m}$
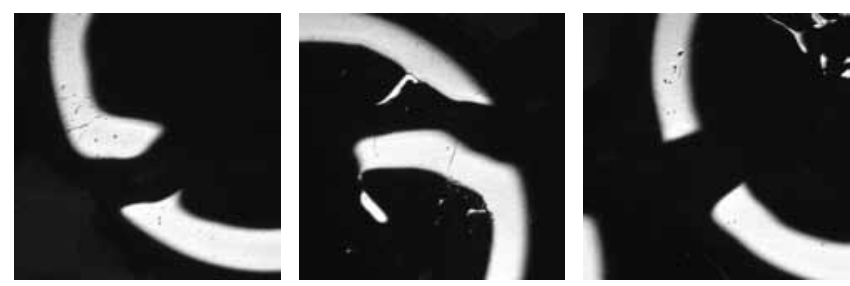

Rys. 8. Przekroje poprzeczne drutu z widocznymi przerwami w obwodzie metalowej otoczki - drut A

Fig. 8. Cross-sections of wires with evidently no overlapping of metal halo - wire $A$
$\mathrm{Ra}=1,79 \mu \mathrm{m}$ oraz wartość $\mathrm{Rz}=60,71 \mu \mathrm{m}$. Dla drutu $\mathrm{B}$ wartości parametru wyniki były następujące: $\mathrm{Ra}=0,90 \mu \mathrm{m}, \mathrm{Rz}=17,18 \mu \mathrm{m}$ (rys. 5 i 6 , tabl. III).

Z punktu widzenia trwałości podzespołów urządzeń do natryskiwania o jakości drutów decyduje również metalowa otoczka zamykająca wewnątrz sypki rdzeń. Wykonano pomiary geometrii w celu stwierdzenia symetrii kołowej bądź owalizacji oraz efektu domykania krawędzi i szczelności otoczki dla sypkiego rdzenia. Formowaniu metalowej taśmy do postaci rurowej często towarzyszy zjawisko relaksacji. Wówczas sypki rdzeń może swobodnie przemieszczać się we wnętrzu metalowej otoczki. Znacznie poważniejszy problem występuje, gdy sypki rdzeń wysypuje się przez niedomkniętą otoczkę - wówczas mogą ulec zmianie właściwości warstwy wierzchniej wytworzonej tym drutem. W większości przypadków proszek nie wysypuje się przez powstałą szczelinę po zwinięciu taśmy, jeśli drut jest formowany na zakładkę (rys. 7) [14:17]. W badanym drucie A długość zakładki wynosi ok. $600 \mu \mathrm{m}$ przy grubości materiału otoczki ok. $200 \mu \mathrm{m}$. W przypadku kształtowania doczołowego taśmy do postaci drutu, zjawisko relaksacji powoduje otwieranie się otoczki - obwód nie zostaje zamknięty i przez powstałą szczelinę sypki rdzeń może wysypywać się na zewnątrz (rys. 8). Prawdopodobieństwo jest szczególnie duże wówczas, gdy rozmiar szczeliny jest porównywalny lub większy od rozmiaru drobin sypkiego rdzenia. Wymiary szczelin w drucie A wynoszą od ok. 150 do ok. $230 \mu \mathrm{m}$ (rys. 9), natomiast wymiary najmniejszych drobin sypkiego rdzenia wynoszą ok. $100 \mu \mathrm{m}$ (rys. 1). W wyniku takich relacji co do wielkości możliwe jest wysypywanie się sproszkowanego rdzenia przez szczelinę i powstawanie wewnątrz drutu pustych przestrzeni. Powstają wówczas zakłócenia podczas natryskiwania łukowego oraz mogą ulec zmianie właściwości wytworzonej warstwy natryskiwanej.

Wypełnienie metalowej otoczki, o jednakowej grubości, sypkim rdzeniem określono za pomocą pomiarów masy odcinków drutu o takiej samej długości wynoszącej $375 \mathrm{~mm}$. W przypadku drutu A największa masa ma wartość $4,582 \mathrm{~g}$, a najmniejsza 3,506 g. Różnica między nimi wynosi 1,076 g, co stanowi ok. $25 \%$ średniej masy pojedynczego odcinka drutu A. Dla drutu B największa masa wynosi 4,312 g, a najmniejsza 4,270 g. Stąd różnica pomiędzy największą i najmniejszą masą jest równa

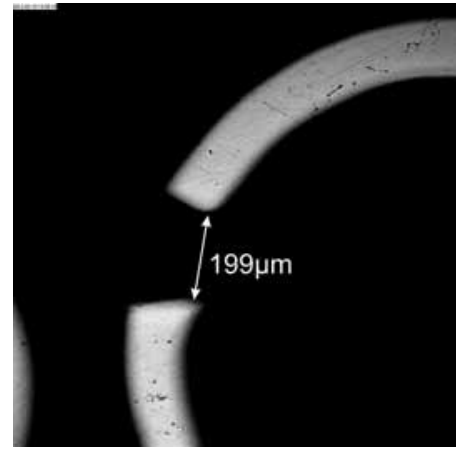

Rys. 9. Przykładowy przekrój poprzeczny drutu z wymiarem szczeliny w miejscu niedomkniętych krawędzi metalowej taśmy - drut A

Fig. 9. Example of cross-section of wire with the gap size between the unclosed edges of metal halo - wire A 


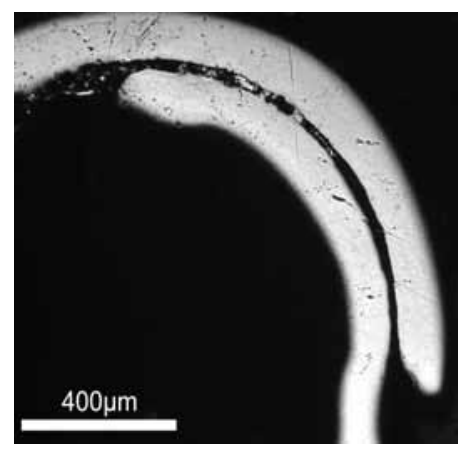

Rys. 10. Przekrój poprzeczny i wielkość zakładki powstałej podczas formowania drutu - dla B wynosi ok. $1200 \mu \mathrm{m}$ Fig. 10. Cross-section and size of overlap create during of wire forming process - for $B$ wire it amount about $1200 \mu \mathrm{m}$

0,042 g, co stanowi ok. $1 \%$ średniej masy pojedynczego odcinka drutu B. Ponadto przeprowadzono obserwację obecności sypkiego rdzenia w 10-milimetrowych odstępach na odcinkach wynoszących $10000 \mathrm{~mm}$ i stwierdzono 4-krotnie brak obecności rdzenia w przypadku drutu A. Długości odcinków drutu bez wypełnienia sięgały $170 \div 300 \mathrm{~mm}$. Dla drutu $B$ stwierdzono obecność rdzenia na całej długości obserwowanych odcinków.

W przypadku drutu B zaobserwowano całkowite wypełnienie metalowej otoczki sypkim rdzeniem bez występowania pustych przestrzeni wewnątrz drutu. Pomimo występującego zjawiska relaksacji oraz bardzo małych wymiarów drobin sypki rdzeń pozostał nieruchomy (nie przesypywał się luźno) wewnątrz drutu. We wszystkich przypadkach nastąpiło zamknięcie drutu na zakładkę o bardzo zbliżonej długości zakładki wynoszącej średnio $1200 \mu \mathrm{m}$ przy grubości otoczki ok. $150 \mu \mathrm{m}$ (rys. 10).

$\mathrm{Na}$ podstawie pomiarów średnic przekrojów poprzecznych drutów na zgładach metalograficznych nie stwierdzono występowania owalności żadnego $z$ nich.

\section{Badanie warstw natryskiwanych drutami proszkowymi}

Z zastosowaniem badanych drutów A i B wytworzono warstwy na przygotowanym podłożu o rozwiniętej powierzchni, za pomocą natryskiwania łukowego [18]. Wykorzystano to samo urządzenie, posługując się takimi samymi parametrami procesu. Natryskiwanie wykonano na dwóch oddzielnych elementach, $z$ których pobrano próbki do badań z trzech różnych przypadkowo wybranych miejsc.

Wykonano pomiary twardości warstw na ich powierzchni za pomocą urządzenia Innovatest Nexus. Zastosowano metodę Vickersa $\mathrm{z}$ obciążeniem wgłębnika siłą 2,94 N skierowaną prostopadle do powierzchni warstwy. Wykonano pomiary w miejscach pobrania próbek oraz wyznaczono wartość średnią. Twardość warstwy wytworzonej za pomocą drutu A wynosiła $890 \mathrm{HV} 0,3$, a warstwy utworzonej za pomocą drutu B - 1090 HV0,3 (tabl. IV).

W celu określenia mikrostruktury i składu chemicznego wytworzonych warstw wykonano badania przy użyciu mikroskopu elektronowego Vega 5135 o zdolności rozdzielczej $3,5 \mathrm{~nm}$, współpracującego $z$ detektorem $\mathrm{Si}(\mathrm{Li})$ Pism 2000 produkcji PGT o rozdzielczości spektralnej $135 \mathrm{eV}$. Podczas badań stosowano napięcie przyspieszające 15 i 20 kV. Do precyzyjnego zbadania składu chemicznego zastosowano spektrometr fluorescencji rentgenowskiej Eagle III. W przypadku zastosowania obydwu drutów stwierdzono spójność warstw oraz typową pasmową budowę warstw powstałą podczas odkształcania i zakleszczania się poszczególnych drobin materiału natryskiwanego z charakterystycznymi pasmami tlenkowymi (rys. 15 i 16). Badanie składu chemicznego próbek pobranych z różnych obszarów wykazało zawartość kluczowych pierwiastków w postaci żelaza i manganu w warstwie wytworzonej za pomocą drutu A ok. 3\% Fe oraz $0,2 \%$ $\mathrm{Mn}$ większą niż w warstwie wytworzonej drutem $\mathrm{B}$, zawartość chromu większa o ok. 1,5\% i krzemu o ok. $0,5 \%$ w warstwie wytworzonej drutem $B$, natomiast zawartość boru zbliżona w obydwu warstwach i wynosiła ok. $6 \%$ wag. (tabl. V).

Wykonano badania porowatości warstw nakładanych drutami A i B, uzyskane wyniki przedstawiono w tablicy VI. Warstwa wykonana drutem A charakteryzuje się większą porowatością wynoszącą $10 \%$, natomiast warstwa wykonana drutem B wykazuje mniejszą, $8 \%$ porowatość.

Jednym z czynników decydujących o właściwej funkcjonalności warstwy jest adhezyjne oddziaływanie materiału natryskiwanego i podłoża na powierzchni granicznej. Przekrój poprzeczny powierzchni

Tablica. IV. Twardość warstw w miejscach pobrania próbek oraz średnia wartość twardości warstw

Table. IV. Surfaces hardness in test places and average hardness of surfaces

\begin{tabular}{|c|c|c|}
\hline Nr próbki & $\begin{array}{c}\text { Twardość HV0,3 w miej- } \\
\text { scach pobrania próbek }\end{array}$ & $\begin{array}{c}\text { Średnia twardość } \\
\text { warstw HV0,3 }\end{array}$ \\
\hline A-1 & 893 & \multirow{2}{*}{890} \\
\hline A-2 & 985 & \\
\hline A-3 & 847 & \multirow{2}{*}{1090} \\
\hline B-1 & 927 & \\
\hline B-2 & 1168 & \\
\hline B-3 & 1175 \\
\hline
\end{tabular}

Tablica V. Zawartość pierwiastków w warstwach natryskiwanych drutami proszkowymi, \% wag.

Table V. In percentages contents of elements in surfaces spraying by core wires, \% wt.

\begin{tabular}{|c|c|c|c|c|c|c|}
\hline Pierwiastek & A-1 & A-2 & A-3 & B-1 & B-2 & B-3 \\
\hline Fe & 65,99 & 65,16 & 65,46 & 63,99 & 64,30 & 62,61 \\
\hline B & 5,40 & 6,52 & 6,47 & 6,64 & 5,87 & 6,39 \\
\hline Cr & 27,02 & 26,58 & 26,45 & 26,93 & 28,29 & 29,14 \\
\hline $\mathrm{Si}$ & 1,08 & 1,15 & 1,02 & 2,00 & 1,34 & 1,46 \\
\hline $\mathrm{Mn}$ & 0,52 & 0,59 & 0,60 & 0,44 & 0,21 & 0,40 \\
\hline
\end{tabular}

Tablica VI. Porowatość warstw natryskiwanych drutami A i B Table VI. The roughness of surfaces spraying by $A$ and $B$ wires

\begin{tabular}{|c|c|}
\hline Warstwa & Porowatość, \% \\
\hline A & 10 \\
\hline B & 8 \\
\hline
\end{tabular}


granicznej dla badanych warstw przedstawiono na rysunkach 13 i 14 . Warstwy natryskiwane obydwoma drutami wykazują adhezję materiału natryskiwanego do podłoża wzdłuż całej powierzchni granicznej.

$Z$ rentgenowskiej mikroanalizy strukturalnej warstwy wykonanej drutem A wynika obecność wydzieleń CrMn oraz związków MnSi (rys. 11 i 12). Ponadto w warstwie tej stwierdzono wydzielenia SiC oraz FeB. Warstwa wytworzona za pomocą drutu B charaktery-
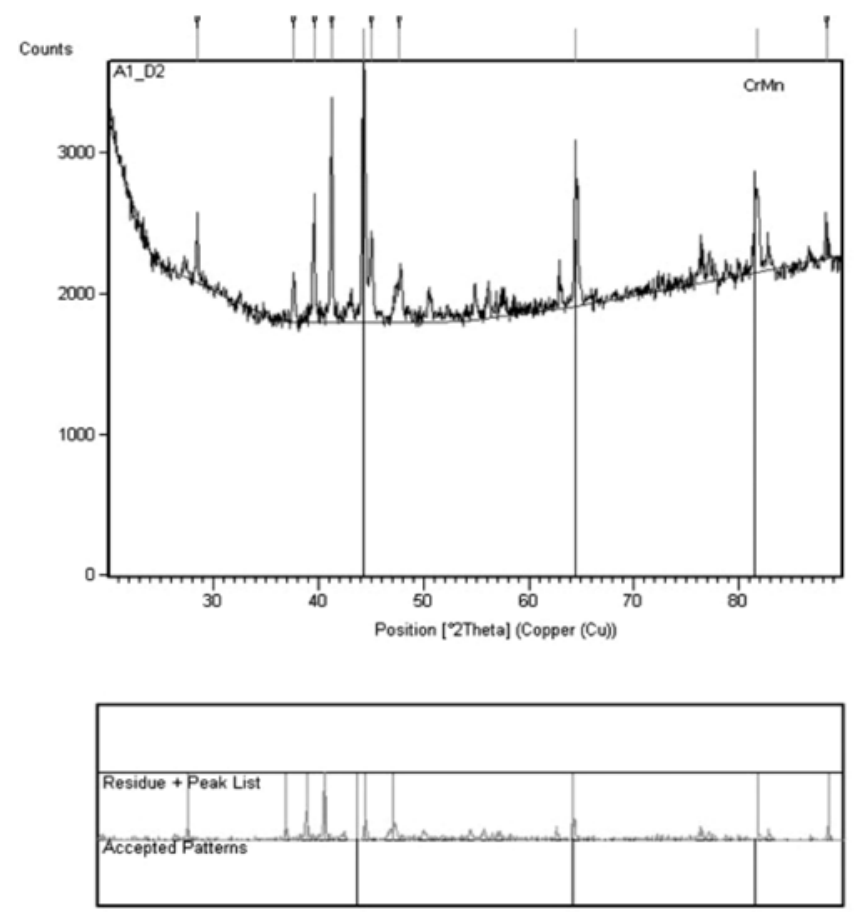

Rys. 11. Dyfraktogram rentgenowski warstwy $A$, wydzielenia $\mathrm{CrMn}$ Fig. 11. X-ray diffraction pattern for the surface $A, C r M n$ precipitation
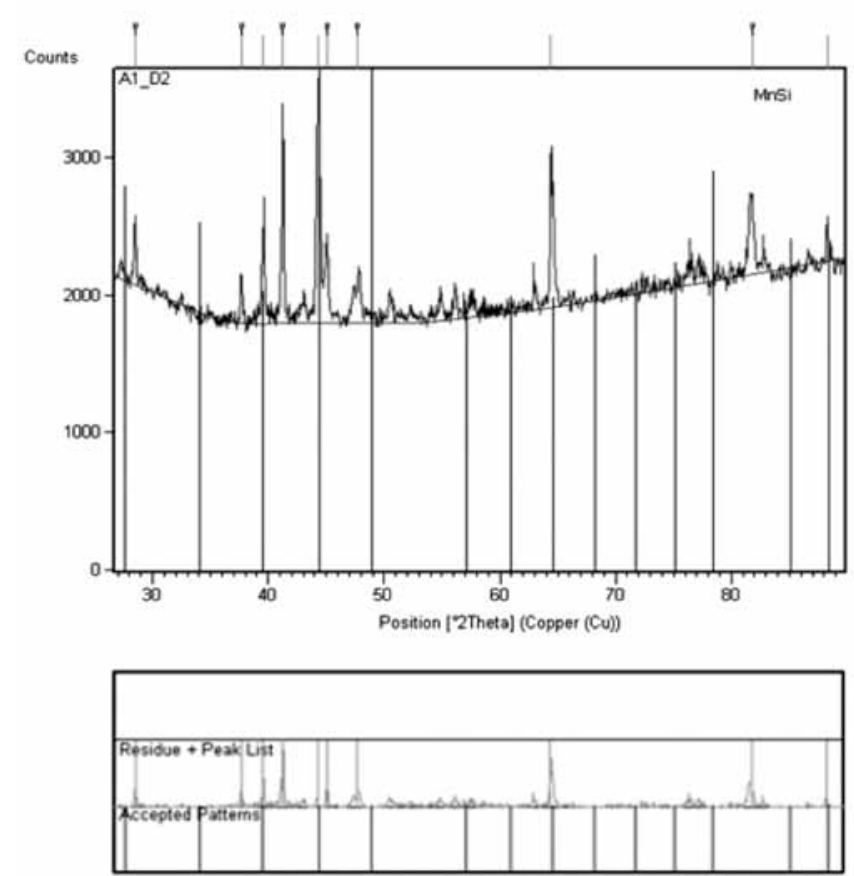

Rys. 12. Dyfraktogram rentgenowski warstwy $\mathrm{A}$, wydzielenia $\mathrm{MnSi}$ Fig. 12. X-ray diffraction pattern for the surface A, MnSi precipitation zuje się występowaniem $\mathrm{CrB}_{2}$ oraz MnSi (rys. 13 i 14). Stwierdzono także obecność $\mathrm{Cr}_{3} \mathrm{Si}$ oraz $\mathrm{Mn}_{2} \mathrm{~B}$.

Przedstawione badania drutów uzupełniono przez określenie zużywania się prowadnic drutu podczas natryskiwania łukowego. Materiał powłokowy w postaci drutu proszkowego A powoduje znacznie szybsze zużywanie się prowadnic drutu niż materiał powłokowy w postaci drutu B. W przypadku drutu A prowadnice zostały zużyte po natryskiwaniu drutu w ilości $9 \mathrm{~kg}$,

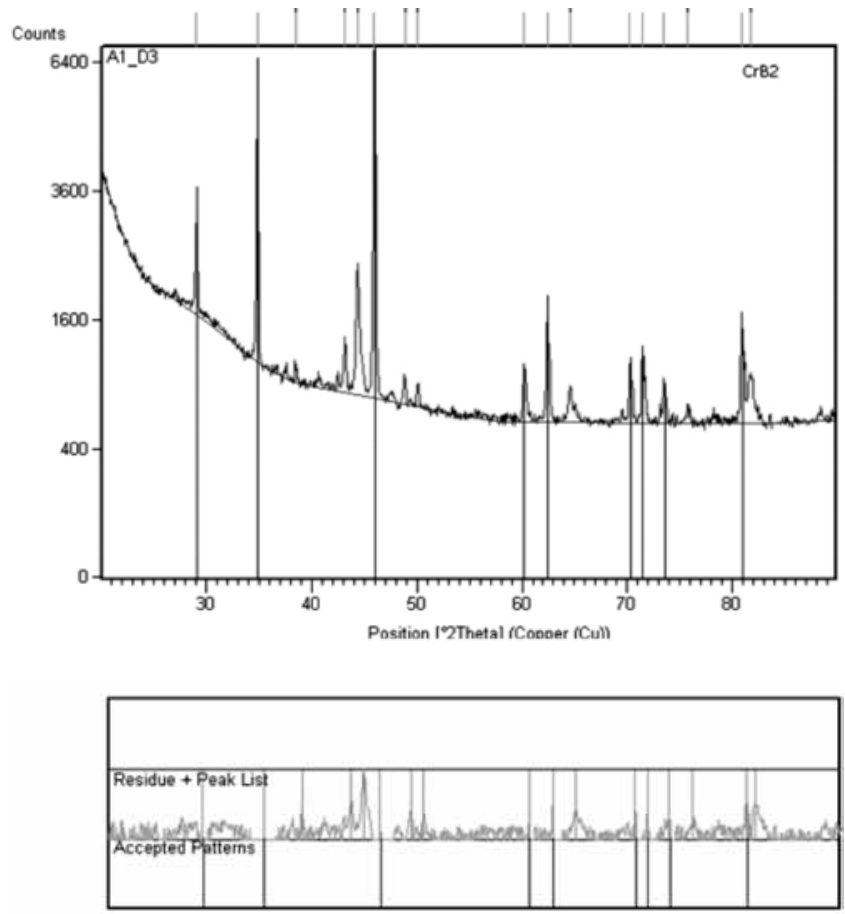

Rys. 13. Dyfraktogram rentgenowski warstwy $B$, wydzielenia $\mathrm{CrB}_{2}$ Fig. 13. X-ray diffraction pattern for the surface $B, \mathrm{CrB}_{2}$ precipitation

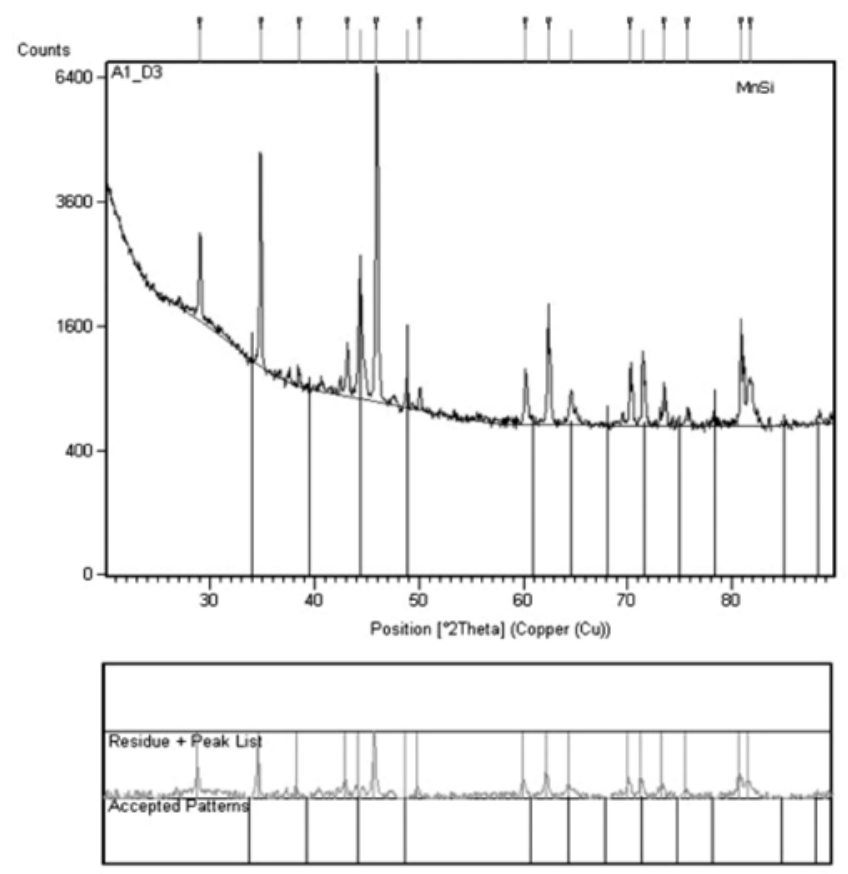

Rys. 14. Dyfraktogram rentgenowski warstwy $B$, wydzielenia $\mathrm{MnSi}$ Fig. 14. $X$-ray diffraction pattern for the surface $B, M n S i$ precipitation 
po czym proces przebiegał w sposób przerywany z powodu zakleszczania się drutu w kanale prowadzącym prowadnicy drutu. Przyczyną zakleszczania się drutu jest wyżłobienie rowka o głębokości dochodzącej, w niektórych miejscach, do średnicy drutu. Proces zużycia jest przyspieszony przez większą chropowatość powierzchni drutu i obecność sypkiego rdzenia między warstwami trącymi metalowej otoczki i kanału prowa-

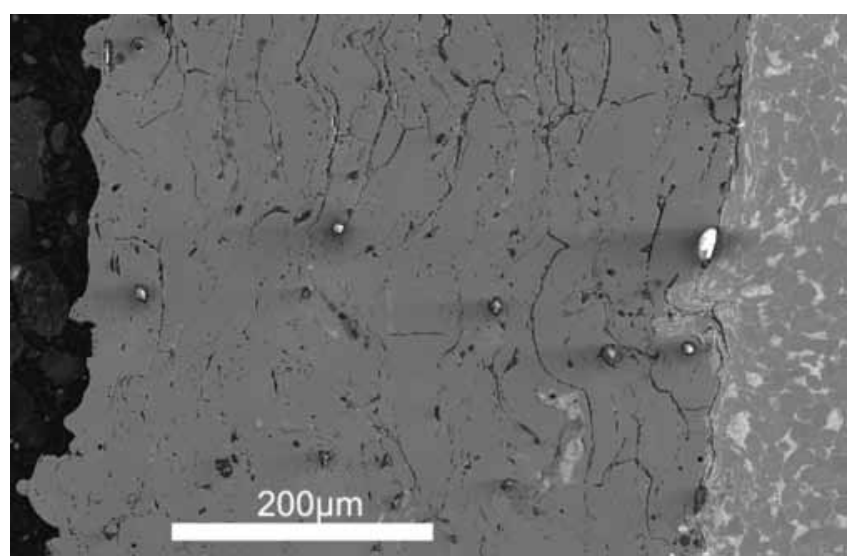

Rys. 15. Przekrój poprzeczny warstwy natryskiwanej drutem A Fig. 15. Cross-section of surface spraying by A wire

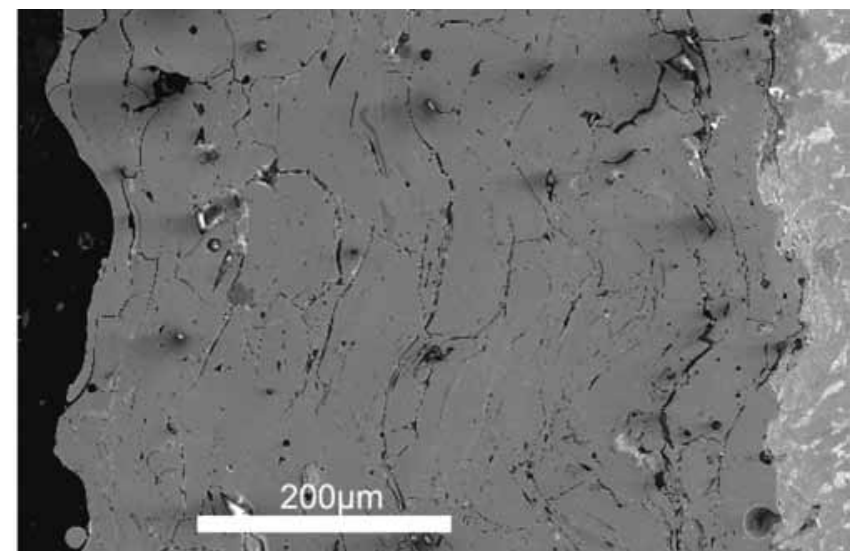

Rys. 16. Przekrój poprzeczny warstwy natryskiwanej drutem B Fig. 16. Cross-section of surface spraying by $B$ wire

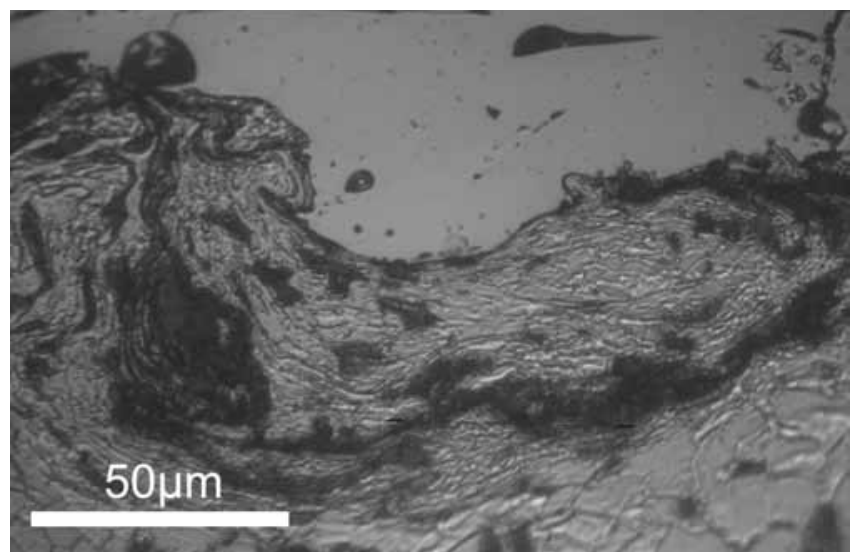

Rys. 17. Przekrój poprzeczny warstwy natryskiwanej drutem A - osadzenie w podłożu stalowym

Fig. 17. Cross section a coating spraying by wire A - deposit on substrate in the form of steel dzącego prowadnicy drutu. Rdzeń drutu jest obecny u wlotu kanału prowadzącego i działa wówczas jak ścierniwo (rys. 19). Prowadnice drutu zastosowane do natryskiwania materiału B wykazują zużycie przez wyżłobione przez drut rowki (rys. 20). Przedstawione zużycie osiągnięto po natryskiwaniu $15 \mathrm{~kg}$ drutu $B$, przy czym nie wystąpiły przerwy ani inne zakłócenia procesu.

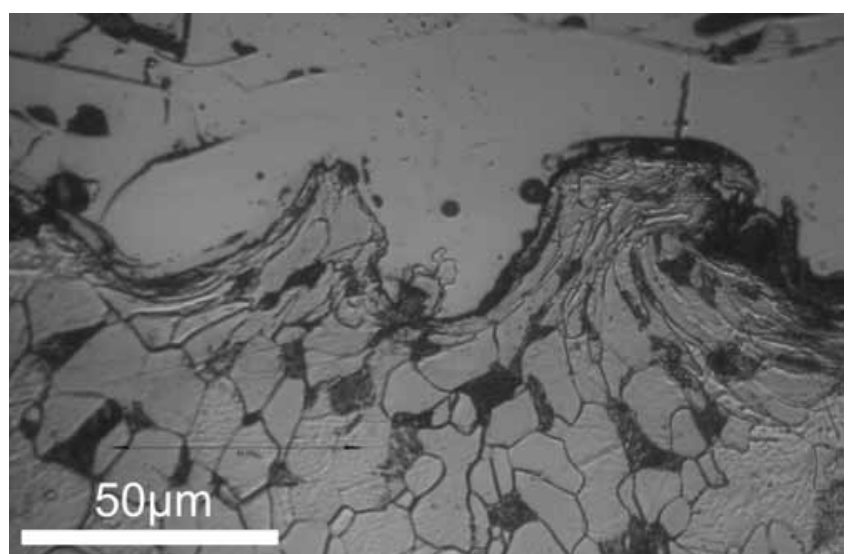

Rys. 18. Przekrój poprzeczny warstwy natryskiwanej drutem B - osadzenie w podłożu stalowym

Fig. 18. Cross section a coating spraying by wire $B-$ deposit on substrate in the form of steel

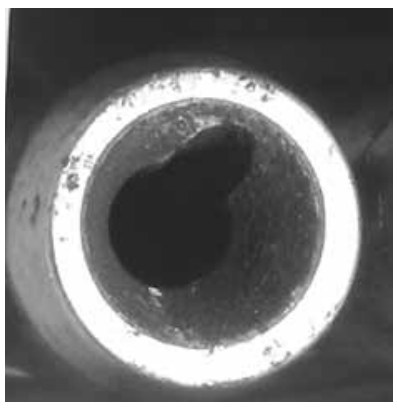

Rys. 19. Widok prowadnicy drutu od strony wlotowej po natryskiwaniu $9 \mathrm{~kg}$ drutu $A$

Fig. 19. View of current terminal on inlet side after the $9 \mathrm{~kg}$ of wire A spraying

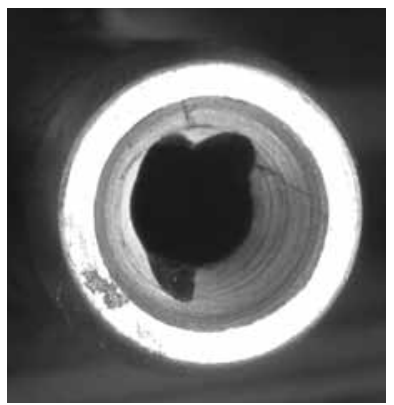

Rys. 20. Widok prowadnicy drutu od strony wlotowej po natryskiwaniu $15 \mathrm{~kg}$ drutu $B$

Fig. 20. View of current terminal on inlet side after the $15 \mathrm{~kg}$ of wire B spraying

\section{Podsumowanie}

Zbadano dwa druty proszkowe A i B formowane z taśmy, wypełnione sypkim rdzeniem metalicznym. W przypadku drutu A drobiny rdzenia mają wymiary od ok. $100 \mu \mathrm{m}$, a na powierzchni widoczne są typowe przełomy o kruchym charakterze (rys. 1). Drut B charakteryzują mocno zróżnicowane co do wielkości drobiny rdzenia o powierzchni podobnej do rdzenia drutu A (rys. 2). 
W badaniach topografii powierzchni za pomoca profilometru stwierdzono znacznie mniejszą chropowatość metalowej otoczki drutu B (rys. 3 i 5), której parametr $\mathrm{Ra}=0,90 \mu \mathrm{m}, \mathrm{a} \mathrm{Rz}=17,18 \mu \mathrm{m}$. Wartości te są znacznie większe dla powierzchni drutu $A$, gdzie $\mathrm{Ra}=1,79 \mu \mathrm{m}, \mathrm{a} \mathrm{Rz}=60,17 \mu \mathrm{m}$ (tabl. III). Obydwa druty zostały utworzone $z$ taśmy przez zawijanie na zakładkę o długości $600 \mu \mathrm{m}$ dla drutu A i długości $1200 \mu \mathrm{m}$ dla drutu B. Ponadto w przypadku drutu A wystąpiły miejsca, gdzie krawędzie nie zachodziły na siebie, tworząc zakładkę i połączone były doczołowo (bez spajania). Występujące zjawisko relaksacji było przyczyną powstawania szczeliny między krawędziami i wysypywania się drobin sypkiego rdzenia widocznych także na powierzchni prowadnic drutu (rys. 8, 9, 19). W przypadku drutu B sypki rdzeń nie wysypywał się z wnętrza metalowej otoczki pomimo znacznie mniejszych wymiarów drobin rdzenia (rys. 10, 20).

Badane druty wykorzystano do natryskiwania łukowego warstw wierzchnich. Wykonano pomiary twardości warstw. Wykazano mniejszą twardość warstwy wytworzonej przy użyciu drutu A wynoszącą $890 \mathrm{HV} 0,3$. Warstwa natryskiwana drutem B charakteryzuje się twardością ok. 1090 HV0,3 (tabl. IV).
Badania mikrostruktury warstwy wykonanej drutem B potwierdziły obecność węglików MC odgrywających znaczną rolę w procesach umocnienia. Zwiększona zawartość dodatków stopowych takich jak chrom i krzem może wpływać na ilościowo większe występowanie pozostałych węglików umacniających stop [4]. Te dwa czynniki mogą być odpowiedzialne za podwyższoną twardość warstwy natryskiwanej drutem B. Obie warstwy wykazują podobną budowę pasmową i kohezję (rys. 15, 16). Na podstawie mikroanalizy składu chemicznego stwierdzono obniżoną zawartość chromu i krzemu w warstwie natryskiwanej drutem A oraz podwyższoną zawartość żelaza (tabl. V). Warstwa utworzona drutem A wykazuje także większą porowatość ok. $10 \%$, a warstwa natryskiwana drutem B - mniejsza na poziomie $8 \%$ (tabl. VI). Obie warstwy wykazują adhezję do podłoża wzdłuż całej powierzchni granicznej (rys. 17, 18). Najszybciej zużywającymi się elementami systemu natryskowego są prowadnice drutu. W przypadku drutu A prowadnice zużywają się szybciej z powodu wyżłobienia głębokiego rowka, w którym zacina się drut. Dla drutu A prowadnice wymagają wymiany po $9 \mathrm{~kg}$, a dla drutu B mogą pracować powyżej $15 \mathrm{~kg}$ natryskiwanego materiału (rys. 19, 20).

\section{Wnioski}

Na podstawie wykonanych badań można stwierdzić, że:

- metoda wytwarzania drutów proszkowych wpływa na jakość wytworzonych warstw przez zmianę składu chemicznego, twardości i porowatości oraz niezakłócony przebieg procesu i trwałość podzespołów urządzeń do natryskiwania łukowego,

- kształtowanie drutów proszkowych z taśmy może być przeprowadzone w sposób zabezpieczający przed wysypywaniem się rdzenia nawet wtedy, kiedy drobiny mają bardzo małe wymiary rzędu kilku $\mu \mathrm{m}$,
- techniki wytwarzania drutów proszkowych umożliwiają wykonanie drutów o przekroju kołowym bez owalizacji,

- drut o zmniejszonej zawartości chromu i krzemu umożliwia wytworzenie warstwy o zmniejszonej twardości (różnica wynosi 200 HV0,3 w porównaniu z drutem o podwyższonej zawartości chromu i krzemu) oraz o $2 \%$ większej porowatości,

- chropowatość powierzchni oraz wysypujący się przez szczelinę metalowej otoczki rdzeń mogą przyspieszać zużycie prowadnic drutu.

\section{Literatura}

[1] Welding Handbook. AWS. Miami, Floryda: 1998, ed. 8, vol. 4 Materials and applications, pt. 2, chapt. 7, s. 409-412.

[2] Klimpel A.: Napawanie i natryskiwanie cieplne. Technologie. WNT Warszawa, 2000.

[3] Wypych A.: Struktura i właściwości napoin nadstopu niklu na stali niskostopowej, Rozprawa doktorska, Poznań 2011.

[4] Katalog materiałów spawalniczych Oerlikon, 2012.

[5] Katalog materiałów spawalniczych Drahtzug Stein, 2012.

[6] Katalog materiałów spawalniczych Messer Eutectic Castolin, 2012.

[7] Materiały spawalnicze Lincoln Electric, 2012.

[8] Materiały spawalnicze ESAB, 2012.

[9] Materiały spawalnicze Corodur Fulldraht GMBH, 2012.

[10] Materiały spawalnicze ThyssenKrupp Energostal, 2012.

[11] Druty do natryskiwania cieplnego Flame Spray Technologies, 2012.

[12] Dokumentacja techniczna pistoletu do natryskiwania łukowego o zamkniętym układzie dyszy produkcji Sulzer Metco, 2012.
[13] Burdek M., Kubiczek M., Marcisz J.: Metody badań topografii powierzchni, składu chemicznego i mikrostruktury powłok cynkowych na wyrobach stalowych. Inżynieria Powierzchni, 2007, nr 2, s. 66-68.

[14] Heywood J., Cross W.: Cored wire review. Svedsaren. 1996, vol. 51 , nr 1-2, s. 3-5.

[15] Lyttle A.: Metal cored wires: were do they fit in your future? Welding Journal, vol. 75, nr 10, s. 35-38.

[16] Welding Handbook. AWS. Miami, Floryda: 1991, ed. 8, vol. 2. Welding processes, chapt. 28, s. 872-874, s. 885-888.

[17] Howes Ch. P.: Thermal spraying: process, preparation, coatings and applications. Welding Journal, 1994, vol. 73, nr 4, s. 47-51.

[18] Schurholt G.: Przygotowanie podłoża do natryskiwania cieplnego. Przegląd Spawalnictwa, nr 12, 2009, s. 43-47. 